\title{
PEMBENTUKAN KEAHLIAN KEJURUAN DI INDUSTRI PERALATAN
}

\author{
Padang Wicaksono ${ }^{1}$, Lionel Priyadi², dan Oscar Vitriano ${ }^{3}$ \\ ${ }^{\top}$ Tenaga Pengajar dan Peneliti senior. Lembaga Demografi. Fakultas Ekonomi Universitas Indonesia \\ ${ }^{2}$ Asisten Pengajar. Fakultas Ekonomi. Universitas Indonesia \\ ${ }^{s}$ Tenaga Pengajar. Fakultas Ekonomi Universitas Indonesia
}

\begin{abstract}
Abstrak - Pasca krisis finansial tahun 1998, pertumbuhan sektor manufaktur di Indonesia didominasi oleh sub-manufaktur peralatan yang padat teknologi. Perkembangan industri peralatan seharusnya meningkatkan permintaan terhadap tenaga kerja terampil dan berkeahlian khusus, yakni tenaga kerja lulusan SMK. Akan tetapi, peran tenaga kerja lulusan SMK relatif semakin berkurang. Walaupun tenaga kerja lulusan SMK memiliki kesempatan untuk berkarir dalam jangka panjang, prospek jenjang karir mereka untuk mencapai posisi setingkat penyelia atau lebih tinggi kurang baik, karena posisi ini diisi oleh tenaga kerja lulusan diploma (D1-D3) atau sarjana maupun pasca sarjana (S1-S3). Rendahnya prospek jenjang karir tenaga kerja lulusan SMK terjadi karena minimnya kesempatan mereka untuk meningkatkan keahliannya (skill upgrading) melalui pelatihan lanjutan di tempat kerja. Hal ini terjadi karena merosotnya posisi industri peralatan dalam nilai rantai global dari orientasi ekspor (export-oriented) menjadi orientasi pasar domestik (domestic marketoriented). Oleh karena itu alih teknologi yang terjadi relatif tidak membutuhkan keahlian yang canggih sehingga cukup dilakukan oleh tenaga kerja terdidik yang kurang terampil seperti lulusan SMA.
\end{abstract}

Abstract - After 1998 financial crisis, the growth of Indonesian manufactures sector had been dominated by the technology intensive-tools and machinery sub sector. The development of tools and machinery sub-sector should have increased the demand for skilled and specific labors namely vocational high school (VHS) graduates. Nevertheless, the VHS graduates' roles had relatively been reduced. Despite they have better opportunities to develop their career in the long term, they are less likely to achieve supervisory or higher career level because the diploma or undergraduates workers most likely occupy the level. One of the main factors behind their lower career level prospects is due to rare opportunities to upgrade their skills through further On the Job Training in the shop floor. Coincidently, this arguably happened due to the declining position of Indonesian tools and machinery industry within global value chain from previously export oriented to domestic market oriented. Therefore, the existing technology transfer relatively hardly needs sophisticated skills which consequently could be delivered by less skilled workers such as general high school (GHS) graduates.

\section{PENDAHULUAN}

Paska krisis finansial tahun 1998, pertumbuhan ekonomi Indonesia mengalami perlambatan signifikan dari rata-rata $7-8 \%$ per tahun mejadi $5-6 \%$ per tahun. Salah satu penyebab perlambatan ini adalah penurunan tingkat pertumbuhan rata-rata di sektor manufaktur (Lihat tabel 1). Sebelum krisis, sektor manufaktur Indonesia tumbuh dengan tingkat rata-rata lebih dari $10 \%$. Pertumbuhan ini ditopang oleh dua submanufaktur, yaitu industri garmen, tekstil, dan alas kaki yang bersifat padat karya dan industri pengolahan kayu yang bersifat padat sumber daya alam (ekstraktif). ${ }^{1}$ Kedua industri

\footnotetext{
${ }^{1}$ Lihat Thee (2012) hal. 156.
} 
ini banyak mempekerjakan tenaga kerja kurang terampil dengan tingkat pendidikan SMP atau lebih rendah. Setelah krisis, kedua industri ini sudah tidak mampu lagi menopang pertumbuhan ekonomi Indonesia, terutama akibat dari regulasi tenaga kerja yang tidak ramah terhadap iklim bisnis (business-unfriendly).2 Melemahnya peranan industri padat karya dan padat sumber daya alam pasca krisis diikuti oleh berkembangnya industri padat teknologi (med-high tech and high tech manufacturing), yakni sub-sektor industri peralatan.

Tabel 1

Rata-rata Pertumbuhan Ekonomi dan

Manufaktur di Indonesia, 1965-2013

\begin{tabular}{|c|c|c|c|c|}
\cline { 2 - 5 } \multicolumn{1}{c|}{} & \multicolumn{4}{c|}{ Rata-Rata Tingkat Pertumbuhan } \\
Per Tahun \\
\cline { 2 - 5 } & $\begin{array}{r}\mathbf{1 9 6 5 -} \\
\mathbf{1 9 8 0}\end{array}$ & $\begin{array}{r}\mathbf{1 9 8 0 -} \\
\mathbf{1 9 9 0}\end{array}$ & $\begin{array}{r}\mathbf{1 9 9 0 -} \\
\mathbf{1 9 9 7}\end{array}$ & $\begin{array}{c}\mathbf{2 0 0 1 -} \\
\mathbf{2 0 1 3}\end{array}$ \\
\hline $\begin{array}{c}\text { Total } \\
\text { PDB }\end{array}$ & 7.0 & 6.1 & 7.7 & 5.5 \\
\hline $\begin{array}{c}\text { Manufak } \\
\text { tur }\end{array}$ & 12.0 & 12.6 & 10.8 & 4.8 \\
\hline
\end{tabular}

Sumber: diolah dari Thee (2012) dan BPS b.

Selama tahun 2001-2013, industri peralatan tumbuh dengan tingkat rata-rata sebesar $10 \%$ per tahun, atau dua kali lipat dari tingkat pertumbuhan manufaktur secara agregat. Pertumbuhan industri peralatan yang pesat juga diikuti oleh perubahan struktural di tingkat sub-manufaktur, dimana terjadi peningkatan proporsi output industri peralatan terhadap total output manufaktur

\footnotetext{
${ }^{2}$ Ibid. hal. 163-164.
}

dari $18 \%$ pada tahun 2000 ke $34 \%$ di tahun 2013. Pesatnya perkembangan industri peralatan yang padat teknologi tentu meningkatkan permintaan atas tenaga kerja terampil (skilled labor), salah satunya adalah tenaga kerja lulusan SMK yang dibekali dengan keterampilan dan pengetahuan teknis yang aplikatif terhadap kegiatan produksi di tingkat bengkel/workshop (workshop-related skill).

Sayangnya analisis empiris menunjukkan hal sebaliknya. Walaupun industri peralatan tumbuh dengan pesat selama periode 20002013, kapasitas industri peralatan Indonesia dari sisi rantai nilai global (global value chain) justru merosot. Hal ini ditandai dengan defisit perdaganganan yang membesar seiring dengan meningkatnya nilai total volume perdagangan. Akibatnya, peranan tenaga kerja lulusan SMK di sektor ini tidak mengalami perkembangan yang signifikan. Merosotnya rantai nilai global dari industri ini memang tidak berpengaruh terhadap kesempatan karir tenaga kerja lulusan SMK dalam jangka panjang di industri ini. Akan tetapi, para pekerja karir lulusan SMK di industri ini tidak akan mendapatkan banyak kesempatan untuk meningkatkan keahlian mereka sehingga akan berpengaruh negatif terhadap proses pembentukan keterampilan mereka.

Artikel ini diorganisasikan sebagai berikut. Bagian II menjelaskan metodologi dan kerangka berpikir yang digunakan. Bagian III membahas perkembagan terkini dari industri peralatan. Bagian IV mengklarifikasi kualitas kondisi kerja dan 
perkembangan karir dari tenaga kerja lulusan SMK di industri ini. Bagian $\mathrm{V}$ berisi kesimpulan, rekomendasi dan saran untuk penelitian selanjutnya.

\section{METODOLOGI DAN KERANGKA BERPIKIR}

Artikel ini akan fokus pada kualitas kondisi kerja dan perkembangan karir dari tenaga kerja lulusan SMK di industri peralatan pasca krisis ekonomi tahun 1998 (2001-2013). Pendekatan yang digunakan adalah metode analisis Pekerjaan yang Layak (Decent Work) ${ }^{3}$ dipadukan dengan analisa rantai nilai global (global value chain) ${ }^{4}$. Adapun, data yang digunakan bersumber dari data SAKERNAS dan Statistik Industri yang diolah dari berbagai tahun sesuai dengan kaidah indikator Pekerjaan yang Layak (Lihat Lampiran) dan nilai rantai global.

\section{KEADAAN INDUSTRI PERALATAN ${ }^{5}$}

\section{Perkembangan Dalam Satu Dekade Terakhir}

Industri peralatan Indonesia berkembang pesat selama periode 2000-2011 (Lihat

\footnotetext{
3 Indikator ini dikembangkan oleh ILO (International Labor Organization). Penjelasan lebih lanjut dapat dilihat di Barrientos et al. (2011), Barrientos, Gereffi, dan Rossi (2010), dan Milberg dan Winkler (2011).

4. Penjelasan lebih lanjut mengenai konsep nilai rantai global dapat dilihat di Ernst dan Kim (2002), Memedovic (2004), dan Kuroiwa dan Heng (2008).

5 Industri peralatan terbagi atas 4 sub-sektor yang diklasifikasikan sebagai berikut, berdasarkan KBLI 2005 (ISIC Rev. 3),

ISIC 29. Industri mesin dan perlengkapannya.

ISIC 30. Industri mesin kantor dan peralatan kantor, akuntansi, dan pengolahan data.

ISIC 31. Industri mesin listrik lainnya.

ISIC 32. Industri radio, televisi, dan peralatan komunikasi.
}

Gambar 1). Dalam kurun waktu tersebut, nilai output industri peralatan meningkat lebih dari dua kali lipat, yaitu dari 70 milyar Rupiah menjadi 185 milyar Rupiah. Perkembangan ini juga diikuti oleh perubahan struktural pada tingkat sub-peralatan (Lihat Tabel 2). Sebelum tahun 2005, sub-sektor radio, televisi, dan peralatan komunikasi adalah industri sub-peralatan terbesar yang memproduksi kurang lebih $60 \%$ dari total output industri peralatan. Setelah tahun 2005, peranan sub-sektor peralatan komunikasi digantikan oleh sub-sektor mesin penghasil listrik dan mesin bukan penghasil listrik, dengan proporsi nilai output sebesar $70 \%$.

Pertumbuhan kapasitas produksi industri peralatan yang pesat sayangnya tidak diikuti dengan peningkatan performa ekspor di pasar global. Sepanjang tahun 2000-2006, industri peralatan adalah eksportir bersih (net-exporter) dengan nilai surplus perdagangan yang berkisar antara 500 juta sampai 3 milyar US\$. Seiring dengan meningkatnya nilai total perdagangan sejak tahun 2007, industri peralatan berubah menjadi importir bersih (net-importer) dengan nilai puncak defisit perdagangan sebesar 30 milyar US $\$$ (20112013).

Perubahan drastis ini mengindikasikan terjadinya perubahan posisi industri peralatan Indonesia dalam sistem rantai nilai global (global value chain), yaitu dari orientasi ekspor (export-oriented) menjadi orientasi domestik (domestic market-oriented). Perubahan persepsi investor manufaktur peralatan global terhadap posisi rantai nilai global Indonesia berpengaruh langsung terhadap permintaan 
tenaga kerja terampil, yakni melalui proses alih teknologi. Alih teknologi dalam domestic market-oriented umumnya bersifat kurang terampil (less-skilled) dan kurang canggih (lesssophisticated) mengingat mutu produk yang dipasarkan di dalam negeri cenderung lebih rendah daripada mutu produk untuk ekspor sehingga berakibat pada kemungkinan kurangnya permintaan terhadap tenaga kerja lulusan SMK di masa mendatang.

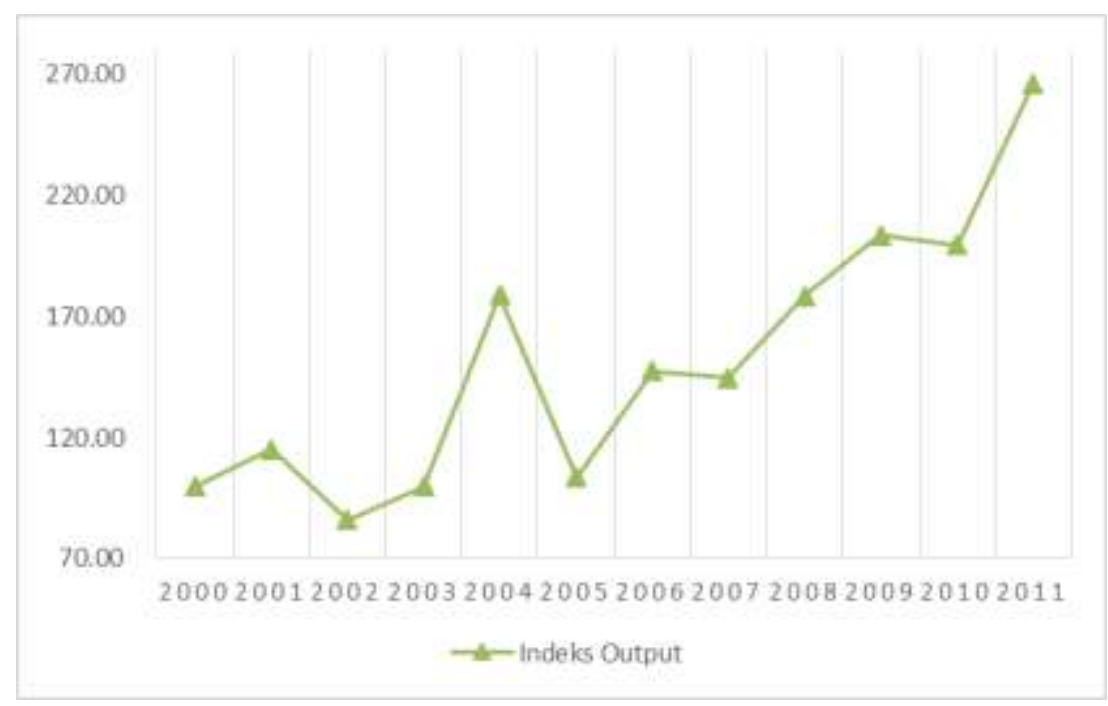

Sumber: diolah dari Statistik Industri, BPS.

Gambar 1

Perkembangan Output Industri Peralatan, dalam Indeks, 2000-2011

Tabel 2

Struktur Industri Peralatan Indonesia, 2000-2011

\begin{tabular}{|c|c|c|c|c|c|c|c|c|c|c|c|c|}
\hline & 2000 & 2001 & 2002 & 2003 & 2004 & 2005 & 2006 & 2007 & 2008 & 2009 & 2010 & 2011 \\
\hline $\begin{array}{l}\text { Industri Mesin dan } \\
\text { Perlengkapan }\end{array}$ & $8.2 \%$ & $46.3 \%$ & $21.7 \%$ & $17.9 \%$ & $11.3 \%$ & $23.3 \%$ & $23.8 \%$ & $21.1 \%$ & $26.1 \%$ & $22.5 \%$ & $14.8 \%$ & $17.8 \%$ \\
\hline $\begin{array}{l}\text { Industri Peralatan } \\
\text { Kantor dan Mesin } \\
\text { Kantor }\end{array}$ & $0.0 \%$ & $0.0 \%$ & $0.1 \%$ & $0.1 \%$ & $0.1 \%$ & $2.4 \%$ & $0.2 \%$ & $0.3 \%$ & $0.4 \%$ & $0.2 \%$ & $1.5 \%$ & $0.5 \%$ \\
\hline $\begin{array}{l}\text { Industri Mesin } \\
\text { Listrik }\end{array}$ & $29.8 \%$ & $21.2 \%$ & $24.6 \%$ & $24.6 \%$ & $26.7 \%$ & $35.3 \%$ & $31.0 \%$ & $33.4 \%$ & $41.2 \%$ & $38.6 \%$ & $46.6 \%$ & $52.7 \%$ \\
\hline $\begin{array}{l}\text { Industri Radio, dan } \\
\text { Peralatan Komunikasi }\end{array}$ & $62.0 \%$ & $32.5 \%$ & $53.6 \%$ & $57.3 \%$ & $61.9 \%$ & $39.0 \%$ & $45.1 \%$ & $45.2 \%$ & $32.3 \%$ & $38.7 \%$ & $37.1 \%$ & $29.0 \%$ \\
\hline
\end{tabular}

Sumber: diolah dari Statistik Industri, BPS. 


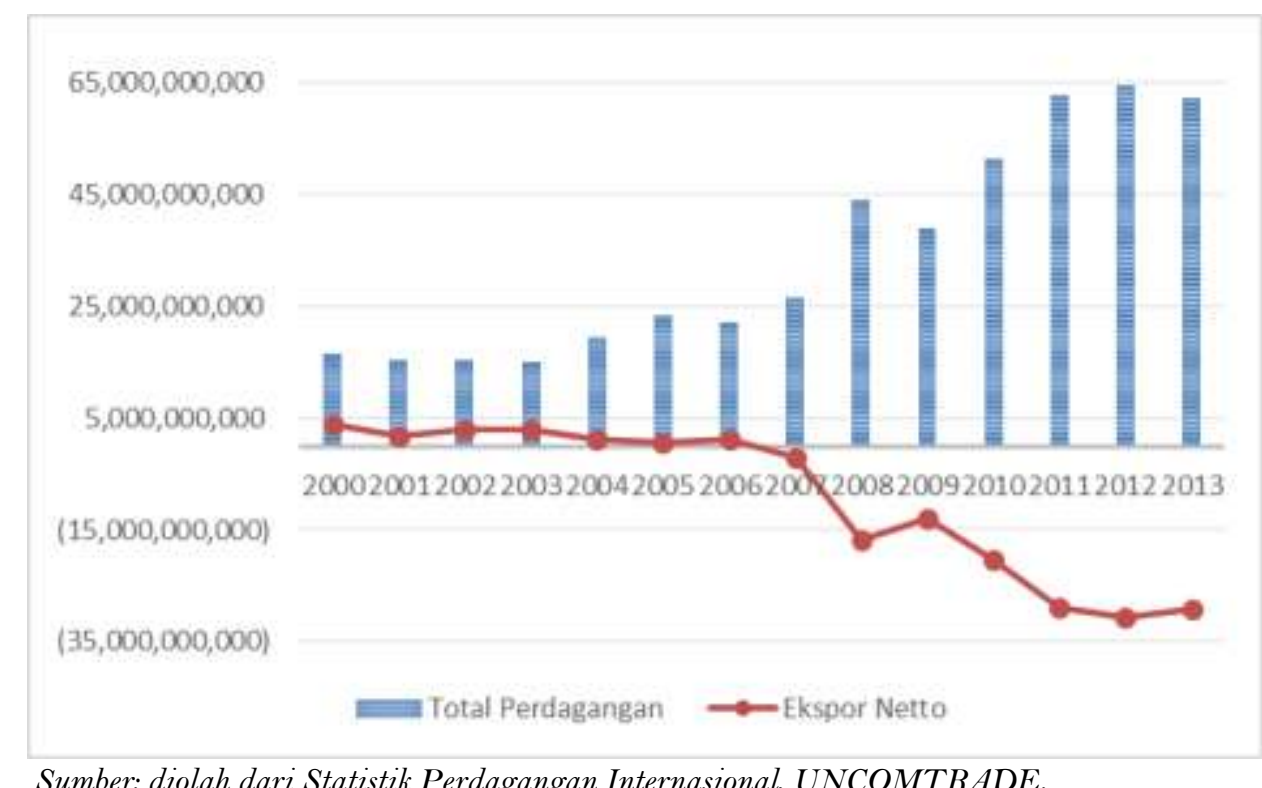

Sumber: diolah dari Statistik Perdagangan Internasional, UNCOMTRADE.

\section{Gambar 2}

Perkembangan Nilai Total Perdagangan dan Ekspor Netto Industri Peralatan, 2000-2013

\section{a. Ringkasan}

Dalam satu dekade terakhir industri peralatan telah mengalami perubahan struktural secara berarti. Pertama, bila pada kurun waktu sebelum 2005 sub-sektor radio, televisi, dan peralatan komunikasi mendominasi output total dalam industri peralatan maka pada periode setelah 2005 dominasi sub-sektor tersebut telah digantikan oleh sub-sektor mesin penghasil listrik dan mesin non-penghasil listrik.

Kedua, sekalipun kapasitas produksi dalam negeri terus meningkat namun sejak tujuh tahun terakhir telah terjadi pergeseran dari semula eksportir bersih menjadi importir bersih.

Ketiga, seiring dengan transisi yang terjadi pada poin kedua, industri peralatan Indonesia telah mengalami perubahan dalam peta rantai nilai global dari semula berorientasi ekspor menjadi berorientasi pasar dalam negeri.

\section{KEADAAN PEKERJA INDUSTRI PERALATAN}

\section{a. Gambaran Tenaga Kerja Secara Umum}

Komposisi tenaga kerja industri peralatan (Lihat Tabel 3) serupa dengan komposisi outputnya. Sebelum tahun 2005, sebagian besar tenaga kerja di industri peralatan bekerja pada sub-sektor radio, televisi dan peralatan komunikasi, sekitar $66 \%$ dari total pekerja. Seiring dengan perubahan struktur industri peralatan, enam tahun kemudian pada tahun 2012 telah terjadi pergeseran dalam proporsi pekerja dari subsektor tersebut ke sub-sektor mesin penghasil listrik dan mesin non penghasil listrik, yakni sebesar $65 \%$. 
Tabel 3

Struktur Pekerja Industri Peralatan Indonesia, 2001-2012

\begin{tabular}{|c|c|c|c|c|c|c|c|c|c|c|c|c|}
\hline & 2001 & 2002 & 2003 & 2004 & 2005 & 2006 & 2007 & 2008 & 2009 & 2010 & 2011 & 2012 \\
\hline Industri Mesin dan & & & & & & & & & & & & \\
\hline Perlengkapan & $16.6 \%$ & $10.3 \%$ & $19.4 \%$ & $5.7 \%$ & $27.0 \%$ & $28.0 \%$ & $29.7 \%$ & $29.8 \%$ & $29.9 \%$ & $31.4 \%$ & $32.1 \%$ & $28.1 \%$ \\
\hline Industri Peralatan & & & & & & & & & & & & \\
\hline Kantor dan Mesin & & & & & & & & & & & & \\
\hline Kantor, Akuntansi dan & & & & & & & & & & & & \\
\hline Pengolahan Data & $1.9 \%$ & $4.0 \%$ & $1.7 \%$ & $5.2 \%$ & $2.7 \%$ & $2.1 \%$ & $1.9 \%$ & $3.4 \%$ & $3.1 \%$ & $3.2 \%$ & $1.7 \%$ & $1.8 \%$ \\
\hline Industri Mesin Listrik & $22.0 \%$ & $18.2 \%$ & $12.7 \%$ & $16.5 \%$ & $18.0 \%$ & $19.7 \%$ & $19.2 \%$ & $20.1 \%$ & $22.6 \%$ & $15.2 \%$ & $28.7 \%$ & $36.6 \%$ \\
\hline $\begin{array}{l}\text { Industri Radio, } \\
\text { Televisi, dan Peralatan }\end{array}$ & & & & & & & & & & & & \\
\hline Komunikasi & $59.4 \%$ & $67.5 \%$ & $66.3 \%$ & $72.6 \%$ & $52.3 \%$ & $50.3 \%$ & $49.1 \%$ & $46.8 \%$ & $44.4 \%$ & $50.2 \%$ & $37.4 \%$ & $33.5 \%$ \\
\hline
\end{tabular}

Sumber: diolah dari SAKERNAS, BPS.

Perubahan komposisi pekerja antar subindustri peralatan juga diikuti dengan perubahan dalam jumlah total pekerja. Bila sebelum tahun 2005, jumlah pekerja di subsektor radio, televisi dan peralatan komunikasi mencapai 300,000 pekerja maka pada tahun 2012 jumlah pekerja pada subsektor ini berkurang menjadi 172,000 pekerja. Disaat yang bersamaan, pekerja di sub-sektor mesin penghasil listrik dan mesin non penghasil listrik meningkat dari 256,000 pekerja ke 333,000 pekerja. Fakta ini menunjukkan terjadinya pergeseran (shifting) atau realokasi sumber daya manusia di subindustri peralatan selama satu dekade terakhir.

Realokasi sumber daya tenaga kerja di industri peralatan diikuti dengan meningkatnya proporsi pekerja informal. Dalam kurun waktu 10 tahun dari 2001 hingga 2010, proporsi tenaga kerja informal meningkat dari $2.4 \%$ ke $12.5 \%$. Fenomena ini merupakan respon perusahaan terhadap Regulasi Ketenagakerjaan yang semakin ketat dan kecenderungan meningkatnya upah minimum sehingga perusahaan cenderung lebih memilih merekrut tenaga kerja informal terutama di tingkat produksi (operator).

Peningkatan ini menunjukkan bahwa realokasi sumber daya tenaga kerja di subindustri ini diikuti dengan perubahan sistem kontrak kerja dari rekrutmen tetap ke tenaga alih daya (outsourcing). Ada dua bentuk outsourcing yang mungkin dilakukan oleh perusahaan. Pertama, mempekerjakan pekerja sebagai tenaga kerja kontrak dengan memperoleh upah/gaji. Kedua, perusahaan dapat melakukan outsourcing proses produksi kepada pihak penyedia (supplier) eksternal. ${ }^{6}$

6 Untuk mengetahui secara detail bagaimana sistem outsourcing yang diberlakukan, diperlukan studi lapangan (fieldwork) pada tingkat perusahaan, karena pemberlakuan sistem outsourcing berbeda di masing-masing perusahaan dan industri. Sayangnya hal ini diluar cakupan penelitian ini. 


\section{b. Gambaran Tenaga Kerja Lulusan SMK}

Selama tahun 2001-2012, proporsi tenaga kerja lulusan SMK di industri peralatan semakin berkurang, dari 36\% ke 30\% (Lihat Tabel 4). Sementara itu, proporsi tenaga kerja lulusan SMA, yang sama terdidik tapi relatif kurang terampil dibandingkan dengan tenaga kerja lulusan SMK, tidak banyak berubah, berada di kisaran 30-32\%.7 Sementara itu, proporsi tenaga kerja dengan pendidikan dan keahlian yang lebih tinggi, lulusan diploma dan sarjana maupun pasca sarjana, semakin meningkat masing-masing dari $4.3 \%$ ke $5.7 \%$ dan dari $3.4 \%$ ke $6.2 \%$. Menurunnya proporsi tenaga kerja lulusan SMK tidak diikuti dengan penurunan dalam jumlah absolut. Sebaliknya, jumlah tenaga kerja lulusan SMK semakin bertambah dari 124,000 pekerja menjadi 154,000 pekerja. Hal ini menunjukkan bahwa pertumbuhan permintaan tenaga kerja lulusan SMK relatif lebih rendah dibandingkan dengan pertumbuhan permintaan tenaga kerja terdidik lainnya.

${ }^{7}$ Kami mendefinisikan tenaga kerja lulusa SMA sebagai relative kurang terampil (less skilled) dibandingkan dengan tenaga kerja lulusan SMK karena tenaga kerja lulusan SMA memiliki pengetahuan dan keahlian teknis di tingkat bengkel/workshop (workshop related skill) yang lebih rendah dari lulusan SMK. Perlu diingat bahwa definisi ini berbeda dengan tenaga kerja kurang terdidik (less educated). 
Tabel 4

Komposisi Tenaga Kerja Industri Peralatan berdasarkan Tingkat Pendidikan, 2001-2012

\begin{tabular}{|c|c|c|c|c|c|c|c|c|c|c|c|c|}
\hline & 2001 & 2002 & 2003 & 2004 & 2005 & 2006 & 2007 & 2008 & 2009 & 2010 & 2011 & 2012 \\
\hline $\begin{array}{l}\text { SMP atau Lebih } \\
\text { Rendah }\end{array}$ & $25.5 \%$ & $21.1 \%$ & $15.4 \%$ & $20.4 \%$ & $29.5 \%$ & $24.0 \%$ & $29.9 \%$ & $25.2 \%$ & $23.3 \%$ & $16.4 \%$ & $27.4 \%$ & $26.4 \%$ \\
\hline SMK & $36.2 \%$ & $29.9 \%$ & $33.7 \%$ & $35.0 \%$ & $22.8 \%$ & $25.0 \%$ & $27.8 \%$ & $27.3 \%$ & $34.6 \%$ & $35.9 \%$ & $33.4 \%$ & $30.0 \%$ \\
\hline SMA & $30.6 \%$ & $38.0 \%$ & $41.4 \%$ & $29.3 \%$ & $40.5 \%$ & $39.9 \%$ & $34.0 \%$ & $35.7 \%$ & $31.0 \%$ & $38.0 \%$ & $32.2 \%$ & $31.7 \%$ \\
\hline Diploma & $4.3 \%$ & $7.3 \%$ & $5.1 \%$ & $9.2 \%$ & $3.4 \%$ & $4.7 \%$ & $3.2 \%$ & $4.9 \%$ & $5.9 \%$ & $3.5 \%$ & $2.9 \%$ & $5.7 \%$ \\
\hline Universitas & $3.4 \%$ & $3.7 \%$ & $4.3 \%$ & $6.2 \%$ & $3.7 \%$ & $6.3 \%$ & $5.0 \%$ & $6.9 \%$ & $5.2 \%$ & $6.1 \%$ & $4.1 \%$ & $6.2 \%$ \\
\hline
\end{tabular}

Sumber: diolah dari Sakernas, BPS

Meningkatnya permintaan terhadap tenaga kerja lulusan non-SMK mengindikasikan adanya perubahan dalam struktur dan jenis keahlian/ keterampilan. Meningkatnya permintaan tenaga kerja lulusan diploma dan sarjana menunjukkan kebutuhan akan tenaga kerja untuk posisi menengah seperti penyelia (supervisor) dan jabatan manajerial lainnya. Sementara itu, tingginya permintaan terhadap tenaga kerja lulusan SMA menunjukkan semakin pudarnya kebutuhan akan standar keahlian spesifik dan pengetahuan khusus pada tingkat awal/tenaga produksi (shop floor level). Fakta ini mengindikasikan adanya hambatan dalam pembentukan keahlian dan keterampilan (skill formation) di tempat kerja melalui praktek peningkatan keahlian di lapangan sehari-hari (on-the-job skill upgrading).

Rendahnya on-the-job skill upgrading di industri peralatan dapat dicermati dengan data proporsi tenaga kerja yang memperoleh pelatihan bersertifikat (Lihat Tabel 5). Sepanjang tahun 2007-2012, proporsi tenaga kerja yang memperoleh pelatihan bersertifikat menurun sebesar 10\%. Rendahnya aktivitas on-the-job skill upgrading juga terjadi pada tenaga kerja lulusan SMK, dimana proporsi pelatihan bersertifikat tenaga kerja lulusan SMK turun sebesar lima persen menjadi $10.5 \%$.

Rendahnya aktivitas on-the-job skill upgrading mempengaruhi jenjang karir tenaga kerja lulusan SMK, yakni menghambat jenjang karir mereka untuk mencapai posisi pengawas/penyelia (supervisor) dan jabatan manajerial yang lebih tinggi. Seperti yang dijelaskan sebelumnya, hal ini terjadi karena merosotnya posisi industri peralatan Indonesia dalam rantai nilai global sehingga proses alih teknologi yang terjadi cukup membutuhkan tenaga kerja yang relatif kurang terampil (less skilled). 
Tabel 5

Komposisi Tenaga Kerja dengan Pelatihan Bersertifikat di Industri Peralatan, 2007-2012

\begin{tabular}{|c|r|r|r|r|r|r|}
\cline { 2 - 7 } \multicolumn{1}{c|}{} & \multicolumn{1}{c|}{$\mathbf{2 0 0 7}$} & \multicolumn{1}{c|}{$\mathbf{2 0 0 8}$} & \multicolumn{1}{c|}{$\mathbf{2 0 0 9}$} & \multicolumn{1}{c|}{$\mathbf{2 0 1 0}$} & \multicolumn{1}{c|}{$\mathbf{2 0 1 1}$} & \multicolumn{2}{c|}{$\mathbf{2 0 1 2}$} \\
\hline Total Tenaga Kerja & $15.7 \%$ & $9.9 \%$ & $5.1 \%$ & $5.6 \%$ & $9.1 \%$ & $5.5 \%$ \\
\hline SMK & $16.3 \%$ & $6.8 \%$ & $4.7 \%$ & $9.3 \%$ & $13.5 \%$ & $10.5 \%$ \\
\hline
\end{tabular}

Sumber: diolah dari Sakernas, BPS.

Namun, berkurangnya aktivitas on-thejob skill upgrading tidak mempengaruhi kesempatan berkarir dalam jangka panjang bagi lulusan SMK. Sepanjang tahun 20082012, proporsi tenaga kerja lulusan SMK yang bekerja lebih dari 3 tahun meningkat dari 35\% ke 50\% (Lihat Gambar 3). Ini artinya, proporsi tenaga kerja kerja lulusan SMK yang menjadi karyawan tetap telah meningkat sehingga peluang untuk mendapatkan jaminan kerja yang lebih layak menjadi lebih besar. Mengapa ini dapat terjadi?

Hal ini terjadi karena peningkatan produktivitas yang pesat dari tenaga kerja lulusan SMK, yang diukur dalam upah per jam kerja perorangan (wage per man-hours -Lihat Gambar 4). Fakta ini menunjukkan bahwa tenaga kerja lulusan SMK tetap bekerja secara produktif sehingga memiliki jenjang karir dalam jangka panjang sekalipun mengalami kesulitan untuk mencapai posisi yang memerlukan keahlian manajerial.

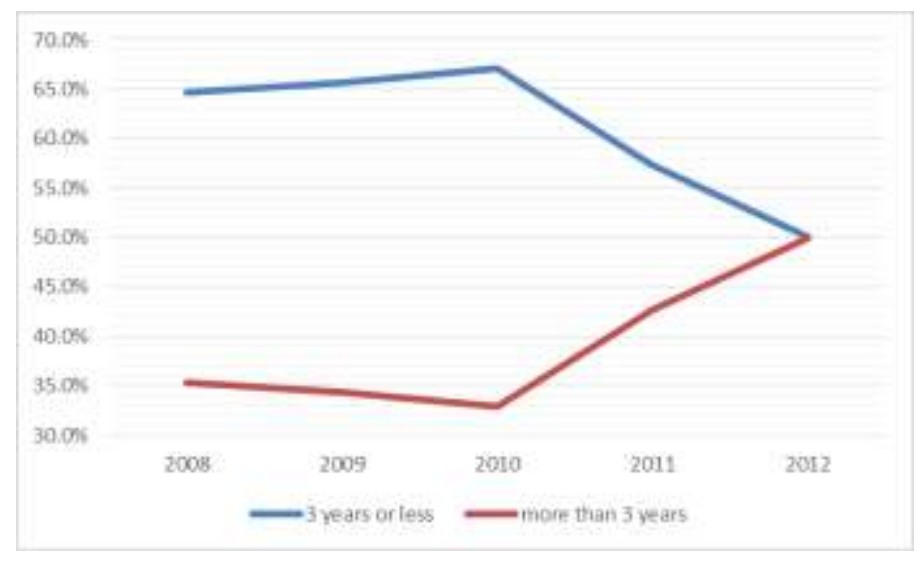

Sumber: diolah dari Sakernas, BPS.

Gambar 3

Proporsi Lama Kerja Tenaga Kerja Lulusan SMK di Industri Peralatan, 2008-2012 


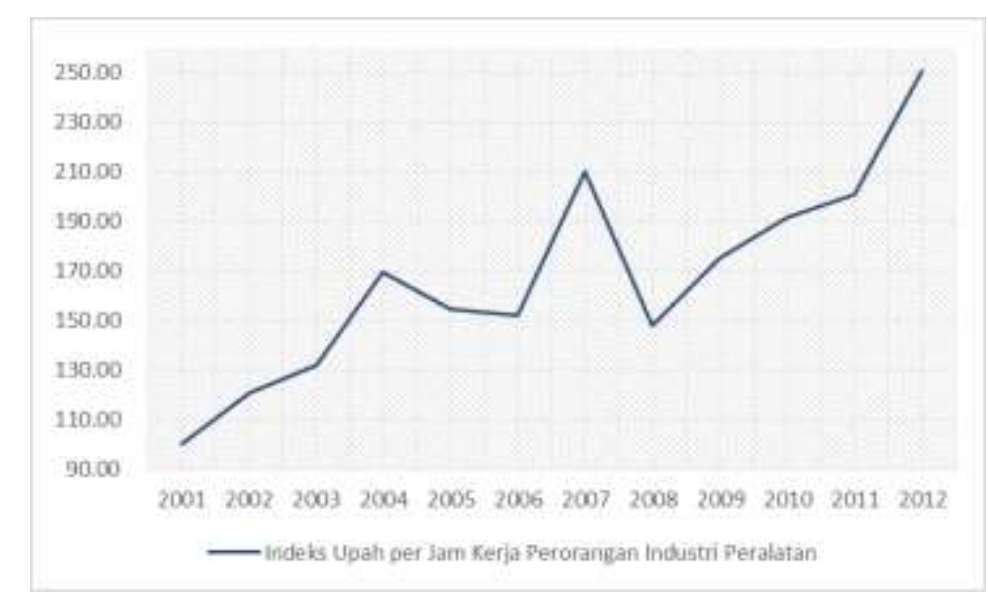

Sumber: diolah dari Sakernas, BPS.

Gambar 4

Trend Produktivitas Upah Tenaga Kerja Lulusan SMK di Industri Peralatan, dalam Indeks, 2001-2012

\section{c. Ringkasan}

Dalam satu dekade terakhir telah terjadi realokasi sumber daya manusia pada industri peralatan. Pertama, proporsi tenaga kerja semakin terkonsentrasi ke sub-sektor mesin penghasil listrik dan mesin bukan penghasil listrik. Ini mengikuti pola yang terjadi pada pergeseran outputnya.

Kedua, pergeseran proporsi pada tingkat sub-sektor ini juga diikuti dengan meningkatkan proporsi pekerja informal. Meningkatnya proporsi pekerja informal diduga sebagai respon perusahaan atas regulasi ketenagakerjaan dan kecenderungan upah minimum yang terus meningkat setiap tahun sehingga lebih fleksibel dan praktis bagi perusahaan untuk mempekerjakan tenaga kerja informal terutama pada tingkat operator.

Ketiga, proporsi tenaga kerja yang memiliki keahlian kejuruan setingkat SMK telah menurun walaupun secara absolut jumlahnya terus meningkat sementara pertumbuhan permintaan terhadap tenaga kerja lulusan non-SMK terutama diploma dan sarjana cenderung meningkat. Ini menunjukkan adanya peningkatan kebutuhan terhadap tenaga kerja yang memiliki keahlian manajerial.

Keempat, sekalipun demikian, proporsi tenaga kerja lulusan pendidikan kejuruan yang menjadi karyawan tetap cenderung meningkat. Ini merupakan sinyal yang positif mengingat dengan menjadi karyawan tetap maka mereka akan memperoleh jaminan kesejahteraan yang lebih baik.

\section{KESIMPULAN DAN REKOMENDASI}

Dari pemaparan di atas dapat disimpulkan beberapa poin penting sebagai berikut. Pertama, dalam satu dekade terakhir industri peralatan di Indonesia telah mengalami transformasi, baik dari sisi struktur maupun orientasi pasarnya. Telah terjadi pergeseran dalam struktur dari semula 
didominasi oleh sub-sektor radio, televisi, dan peralatan komunikasi beralih menjadi dominasi sub-sektor mesin penghasil listrik dan mesin non-penghasil listrik. Dari sisi orientasi pasar telah terjadi pergeseran dari semula berorientasi ekspor menjadi berorientasi pasar dalam negeri. Peralihan ini ditunjukan oleh indikator berupa meningkatnya kapasitas produksi dalam negeri namun justru diiringi dengan status industri peralatan yang praktis menjadi importir bersih.

Kedua, transformasi dalam struktur maupun orientasi pasar industri peralatan diikuti pula oleh realokasi sumber daya manusia yang terlibat di dalamnya. Yang patut digaris-bawahi dalam realokasi sumber daya pekerja ini adalah semakin memudarnya kebutuhan terhadap keahlian dan keterampilan spesifik pada tingkat operasional produksi. Ini ditandai dengan terus menurunnya proporsi tenaga kerja berkeahlian kejuruan (lulusan SMK) sementara proporsi tenaga kerja berkeahlian umum (lulusan SMA) tidak jauh berbeda dengan pekerja lulusan pendidikan kejuruan. Fenomena ini ternyata juga diperkuat dengan begitu sedikitnya proporsi pekerja yang memperoleh pelatihan bersertifikat terutama dalam lima tahun terakhir proporsinya praktis di bawah 10 persen dari total tenaga kerja di industri peralatan sehingga tidak mengherankan bila proporsi pekerja informal juga meningkat tajam lebih dari lima kali lipat dalam sepuluh tahun terakhir.

Ketiga, sekalipun proporsi pekerja berkeahlian kejuruan telah menurun dan kemungkinan menduduki posisi manajerial tidak begitu besar namun proporsi mereka yang memiliki masa kerja lebih lama atau menjadi karyawan tetap terus meningkat. Ini disebabkan oleh faktor berupa produktivitas mereka yang terus meningkat pesat. Dengan menjadi karyawan tetap dan memiliki masa kerja lebih lama maka para pekerja berkeahlian kejuruan memiliki keuntungan berupa tunjangan kesejahteraan yang lebih baik dan terjamin.

Dari tiga poin utama kesimpulan di atas dapat direkomendasikan beberapa hal untuk penelitian selanjutnya. Pertama, perlu dilihat karakter, struktur, sifat, transformasi industri peralatan dunia berikut posisi industri peralatan Indonesia dalam konteks rantai nilai global mengingat studi ini belum melakukan hal tersebut secara rinci.

Kedua, dari sisi data, perlu dilakukan studi lapangan di tingkat mikro/perusahaan mengingat baik data SAKERNAS maupun Statistik Industri memiliki keterbatasan dalam menggali proses pembentukan keahlian/keterampilan kejuruan/vokasional maupun strategi perusahaan dalam merespon regulasi ketenagakerjaan berikut tranformasi struktur industri yang bersangkutan. 


\section{DAFTAR PUSTAKA}

Barrientos, Stephanie, Frederick Mayer, John Pickles, and Anne Posthuma. 2011. "Decent Work In Global Production Networks: Framing The Policy Debate." International Labour Review 150 (3-4): 299-317.

Barrientos, Stephanie, Gary Gereffi, and Arianna Rossi. 2011. "Economic And Social Upgrading In Global Production Networks: A New Paradigm For A Changing World.” International Labour Review 150 (3-4): 319-340.

Ernst, Dieter, and Linsu Kim. 2002. "Global Production Networks, Knowledge Diffusion, and Local Capability Formation.” Research Policy 31: 1417-129.

Kuroiwa, Ikuo, and Toh Mun Heng (eds) 2008. Production Networks and Industrial Clusters: Integrating Economies in Southeast Asia. Singapore: ISEAS.

Memedovic, Olga. 2004. "Inserting Local Industries into Global Value Chains and Global Production Networks: Opportunities and Challenges for Upgrading With a Focus on Asia." UNIDO Working Paper.

Milberg, William, and Deborah Winkler. 2011. "Economic And Social Upgrading In Global Production Networks: Problems Of Theory And Measurement." International Labour Review $150(3-4): 341-365$.

Thee, K.W. 2012. "Indonesia's Industrial policies and Development since Independence." In Indonesia's Economy Since Independence. Thee Kian Wie. ISEAS: 141-174. 